\title{
Analisis pengaruh inflasi, pendidikan dan pertumbuhan ekonomi terhadap tingkat pengangguran terbuka dan kemiskinan di Provinsi Jambi
}

\author{
M. Azis*; Yulmardi; Nurhayani \\ Prodi Ekonomi Pembangunan Fak.Ekonomi dan Bisnis Universitas Jambi \\ *E-mail korespondensi: mazis349@gmail.com
}

\begin{abstract}
The purposes of this study are 1) To determine and analyze the development of inflation, education, economic growth, open unemployment, and poverty in Jambi Province; and 2) To determine and analyze the effect of inflation, education, and economic growth, on the open unemployment rate and poverty in Jambi Province. The data used in this research is secondary data. The model used in this study is a multiple linear regression model. The results show that the average development of inflation is $11.35 \%$, education is $1.25 \%$, economic growth is $-2.64 \%$, TPT is $1.99 \%$, and poverty is $-2.74 \%$. Furthermore, the analysis results show that directly inflation and economic growth have a significant effect on TPT in Jambi Province $(P<0.05)$. At the same time, indirectly, only education variables affect poverty in Jambi Province $(P<0.05)$.
\end{abstract}

Keywords: Inflation, Education, Economic growth, Open unemployment, Poverty

\begin{abstract}
Abstrak
Tujuan dari penelitian ini adalah 1) Untuk mengetahui dan menganalisis perkembangan inflasi, pendidikan, pertumbuhan ekonomi, tingkat pengangguran terbuka dan kemiskinan di Provinsi Jambi; dan 2) Untuk mengetahui dan menganalisis pengaruh inflasi, pendidikan, dan pertumbuhan ekonomi, terhadap tingkat pengangguran terbuka dan kemiskinan di Provinsi Jambi. Data yang digunakan dalam penelitian ini adalah data sekunder. Model yang digunakan dalam penelitian ini adalah model regresi linear berganda. Hasil penelitian menunjukkan bahwa rata-rata perkembangan inflasi sebesar $11,35 \%$, pendidikan sebesar $1,25 \%$, pertumbuhan ekonomi sebesar $-2,64 \%$, TPT sebesar $1,99 \%$ dan kemiskinan sebesar $-2,74 \%$. Selanjutnya hasil analisis persamaan pertama menunjukkan bahwa inflasi dan pertumbuhan ekonomi berpengaruh secara signifikan terhadap TPT di Provinsi Jambi $(\mathrm{P}<0,05)$, sedangkan persamaan kedua hanya variabel pendidikan yang mempengaruhi kemiskinan di Provinsi Jambi $(\mathrm{P}<0,05)$.
\end{abstract}

\footnotetext{
Kata kunci: Inflasi, Pendidikan, Pertumbuhan ekonomi, Tingkat pengangguran terbuka, Kemiskinan
}

\section{PENDAHULUAN}

Persoalan kemiskinan saat ini menjadi salah satu target kebijakan pembangunan pemerintah baik tingkat nasional maupun regional. Selama ini sudah banyak programprogram pembangunan yang dipusatkan oleh pemerintah dalam upaya pengentasan kemiskinan. Namun, upaya yang dilakukan pemerintah tersebut sampai saat ini belum 
sepenuhnya mampu memecahkan masalah kemiskinan yang selama ini masih mengganjal pembangunan.

Provinsi Jambi merupakan salah satu wilayah yang juga dihadapkan pada permasalahan mengenai penduduk miskin. Banyak faktor yang mempengaruhi jumlah penduduk miskin di Provinsi Jambi, salah satunya adalah banyaknya tingkat pengangguran terbuka. Pengangguran akan menimbulkan efek mengurangi pendapatan masyarakat, dan hal itu akan mengurangi tingkat kemakmuran yang telah dicapai.Pengangguran adalah seseorang yang tergolong angkatan kerja dan ingin mendapat pekerjaan tetapi belum dapat memperolehnya. Ada hubungan yang erat sekali antara tingginya tingkat pengangguran, luasnya kemiskinan, distribusi pendapatan yang tidak merata. Bagi sebagian besar mereka, yang tidak mempunyai pekerjaan yang tetap atau hanya bekerja paruh waktu (part time) selalu berada diantara kelompok masyarakat yang sangat miskin (Arsyad, 2010).

Selain tingkat pengangguran terbuka, inflasi dan pertumbuhan ekonomi juga mempengaruhi kemiskinan di suatu daerah. Inflasi yang merupakan variabel makro ekonomi selain pertumbuhan dan pengangguran semestinya mendapatkan perhatian penuh dari Pemerintah dalam hal menjaga tingkat kestabilannya. Setelah dahsyatnya goncangan krisis finansial 1998 yang merembet pada krisis kepercayaan, ekonomi Provinsi Jambi mulai bergerak dan bangkit kembali. Pertumbuhan ekonomi merupakan salah satu syarat suatu bangsa untuk memajukan bangsanya atau menaikan kesejahteraan warganya. Walaupun pertumbuhan ekonomi tidak bisa berdiri sendiri untuk mengurangi kemiskinan namun pertumbuhan ekonomi menjadi satu faktor yang tidak bisa disingkirkan untuk mengentaskan kemiskinan.

Jumlah penduduk miskin di Provinsi Jambi selama tahun 2015-2019 rata-rata sebanyak 288.94 ribu orang $(8,23 \%)$. Jumlah penduduk miskin di Provinsi Jambi mengalami penruunan dari tahun ketahun. Jumlah penduduk miskin di Provinsi Jambi tertingi pada tahun 2015yaitu 311.56 ribu orang (9,12\%). Selanjutnya pada tahun berikutnya jumlah penduduk miskin di Provinsi Jambi terus mengalami penurunan hingga 274.32 ribu orang $(7,60 \%)$ pada tahun 2019.Hal ini menunjukkan bahwa pemerintah Provinsi Jambi cukup berhasil dalam usaha pengentasan kemiskinan.

Selanjutnya tingkat pengangguran terbuka di Provinsi Jambi selama tahun 20152019 cendrung mengalami penurunan. Tahun 2015 tingkat pengangguran terbuka sebesar 4,34\%. Angka tingkat pengangguran terbuka tersebut terus mengalami penurunan sampai tahun 2018 menjadi 3,59\%. Akan tetapi, pada tahun 2019 tingkat pengangguran terbuka di Provinsi Jambi justru mengalami menjadi 3,92\%. Naik turunnya tingkat pengangguran terbuka di Provinsi Jambi diduga ada kaitannya dengan laju inflasi dan pertumbuhan ekonomi pada tahun-tahun tersebut. Menurut (Delis, Mustika dan Umiyati, 2015) masalah kemiskinan dan pengangguran memiliki keterkaitan satu sama lain, sehingga pemerintah harus melakukan penanganan serius untuk menurunkan kemiskinan dengan cara membuka kesempatan kerja yang dapat menyerap tenaga kerja, sehingga dapat menurunkan jumlah kemiskinan dan menurunkan angka pengangguran.

Adapun inflasi dan pertumbuhan ekonomi di Provinsi Jambi tahun 2015-2019 rata-rata inflasi di Provinsi Jambi sebesar $0,31 \%$ dengan raata-rata pertumbuhan ekonomi sebesar 4,32\%. Inflasi tertinggi terjadi pada tahun 2016 yaitu 1,19\% dengan pertumbuhan ekonomi sebesaar 3,51\%. Dalam pembangunan ekonomi ada juga saatsaat kegagalan pemerintah membangun ekonomi, kegagalan pertumbuhan ekonomi 
meretas kemiskinan cenderung disebabkan oleh gagalnya pemerintah dalam mengelolah laju pertumbuhan ekonomi. Kegagalan pemerintah dalam mengatur sistem pemberian upah padahal upah adalah sumber penghasilan, bila sumber penghasilan turun atau tetap maka kesejahteraan juga turun atau tetap dan itu juga pasti mempengaruhi tingkat kemiskinan.(Romi dan Umiyati, 2018) pertumbuhan ekonomi sangat berarti dalam peningkatan kesejahteraan masyarakat melalui penciptaan dan perluasan kesempatan kerja dan kesempatan berusaha. Dengan kata lain pertumbuhan ekonomi tersebut mampu menciptakan terjadinya trickle down effect melalui penciptaan dan penyerapan tenaga kerja yang pada gilirannya diharapkan akandiikuti oleh semakin banyak penduduk yang memperoleh pendapatan yang akhirnya akan meningkatkan pertumbuhan ekonomi dan mengurangi kemiskinan.

Kemudian faktor selanjutnya yang mempengaruhi kemiskinan adalah pendidikan. Pendidikan merupakan salah satu hal yang penting dalam berkembangnya pembangunan suatu bangsa sehingga tidak dapat dipandang sebelah mata. Pendidikan berpengaruh negatif terhadap tingkat kemiskinan, semakin meningkat pendidikan seseorang maka akan meningkat juga produktifitasnya, semakin meningkat produktifitas akan semakin meningkat pendapatannya sehingga seseorang semakin mampu untuk memenuhi kebutuhan hidup, semakin terpenuhinya kebutuhan hidup akan mengakibatkan kemiskinan menurun.

\section{METODE}

\section{Jenis dan sumber data}

Data yang digunakan dalam penelitian ini merupakan data sekunder dengan jenis data time series. Data time series yang digunakan dalam penelitian ini adalah data dari tahun 2000-2019 yang bersumber pada laporan Badan Pusat Statistik (BPS), jurnal, penelitian terdahulu, situs we dan sumber lain yang berkaitan dengan penelitian ini. Data yang diteliti meliputi data inflasi, pertumbuhan ekonomi, pendidikan, pengangguran terbuka, dan kemiskinan di Provinsi Jambi pada tahun-tahun tersebut.

\section{Metode analisis data}

Analisis deskriptif di gunakanuntuk menjawab tujuan penelitian pertama yaitu mengetahui dan menganalisis perkembangan inflasi, pendidikan, dan pertumbuhan ekonomi, tingkat pengangguran terbuka dan kemiskinan di Provinsi Jambi dengan rumus perkembangan. Adapun persamaan rumus perkembangan secara umum sebagai berikut:

$$
\text { Perkembangan }=\frac{V_{t}-V_{t-1}}{V_{t-1}} \times 100 \%
$$

\footnotetext{
Keterangan :

$\mathrm{V}_{\mathrm{t}} \quad=$ Nilai tahun terakhir

$\mathrm{V}_{\mathrm{t}-1} \quad$ = Nilai tahun sebelumnya
}

Selanjutnya untuk mengetahui pengaruh Inflasi, Pendidikan, dan Pertumbuhan Ekonomi terhadap tingkat Pengangguran Terbuka dan Kemiskinan digunakan analisis regresi linear berganda dengan data panel yang merupakan kombinasi antar deret waktu dan deret hitung, Model persamaan nya adalah sebagai berikut: 


\section{Persamaan I}

$\mathbf{Y}_{1}=\alpha+\beta_{\mathbf{y} 1 \times 1} I F+\beta_{y 1 \times 2} \mathbf{P E}+\beta_{\mathbf{y} 1 \times 3} \mathbf{P D}+\mathbf{e}$

Keterangan :

$\mathrm{Y}_{1} \quad=$ Tingkat pengangguran

$\alpha \quad=$ Konstanta

$\beta_{\mathrm{y} 1 \mathrm{x} 1, . .} \beta_{\mathrm{y} 1 \times 3}=$ Koefisien

IF $\quad=$ Inflasi

PD $\quad=$ Pendidikan

$\mathrm{PE} \quad=$ Pertumbuhan ekonomi

$\mathrm{e}=$ Standar eror

\section{Persamaan II}

$\mathbf{Y}_{2}=\alpha+\beta_{\mathbf{y} 2 \times 1} \mathbf{I F}+\beta_{\mathrm{y} 2 \times 2} \mathbf{P E}+\beta_{\mathrm{y} 2 \mathrm{x} 3} \mathbf{P D}+\beta_{\mathrm{y} 2 \mathrm{y} 1} \mathbf{T P T}+\mathrm{e}$

Keterangan :

$\mathrm{Y}_{2} \quad=$ Kemiskinan

$\alpha \quad=$ konstanta

$\beta_{\mathrm{y} 2 \mathrm{x} 1, \ldots,} \beta_{\mathrm{y} 2 \mathrm{y} 1}=$ Koefisien

IF $\quad=$ Inflasi

PD $\quad=$ Pendidikan

$\mathrm{PE} \quad=$ Pertumbuhan ekonomi

TPT = Tingkat pengangguran terbuka

e $\quad=$ Standar eror

\section{HASIL DAN PEMBAHASAN}

Perkembangan inflasi, pendidikan dan pertumbuhan ekonomi, tingkat pengangguran terbuka dan kemiskinan di Provinsi Jambi

Selama tahun 2000-2019 rata-rata lajuu inflasi Provinsi Jambi sebesar 6,51\% dengan rata-rata perkembangan setiap tahun sebesaar 11,35\%. Inflasi Provinsi Jambi selama tahun tersebut mengalami fluktuasi sehingga terjadi perkembangan yang naik tururn secara signifikan.

Rata-rata lama sekolah penduduk di Provinsi Jambi selama tahun 2000-2019 cenderung mengalami peningkatan dengan rata-rata sebesar 7,61 tahun dengan rata-rata perkembangan sebesar 1,25\%. Selama tahun 2000-2019 pertumbuhan ekonomi di Provinsi Jambi mengalami fluktuasi dengan rata-rata pertumbuhan ekonomi sebesar $5,97 \%$.

Selama tahun 2000-2019 TPT di Provinsi Jambi rata-rata sebesar 5,17\%. Selanjutnya jumlah penduduk miskin di Provinsi Jambi selama tahun 2000-2019 mengalami penurunan dengan rata-rata jumlah penduduk miskin sebanyak 307.630 jiwa dan perkembangan mengalami penurunan sebesar $2,74 \%$.

Pengaruh inflasi, pendidikan dan pertumbuhan ekonomi terhadap tingkat pengangguran terbuka dan kemiskinan di Provinsi Jambi

Hasil analisis uji regresi linear berganda mengenai pengaruh inflasi, pendidikandan pertumbuhan ekonomiterhadap tingkat pengangguran terbukadi Provinsi Jambi dapat dilihat pada Tabel 1. 
Tabel 1. Hasil analisis regresi linear berganda persamaan pertama

\begin{tabular}{lccc}
\hline \multicolumn{1}{c}{ Variabel Bebas } & $\begin{array}{c}\text { Standardized } \\
\text { Coefficient Beta }\end{array}$ & $\mathbf{t}$ & Sig. \\
\hline Constanta & 1,544330 & 1,951803 & 0,0687 \\
Inflasi $\left(\mathrm{X}_{1}\right)$ & 0,118769 & 3,857966 & 0,0014 \\
Pertumbuhan Ekonomi $\left(\mathrm{X}_{2}\right)$ & $-0,746920$ & 3,218453 & 0,0054 \\
Pendidikan $\left(\mathrm{X}_{3}\right)$ & $-0,362937$ & $-0,434835$ & 0,6695 \\
R Square $\left(\mathrm{R}^{2}\right)=$ & 0,601120 & & \\
Adjusted $\mathrm{R}$ Square $=$ & 0,526330 & & \\
S.E. of Regression $=$ & 0,073771 & & \\
\hline Kererangan $: Y_{l}=$ Tingkt Penganggen & & \\
\hline
\end{tabular}

Keterangan : $Y_{1}=$ Tingkat Pengangguran Terbuka $($ TPT $)$

Berdasarkan Tabel 1. maka diperoleh model persamaan pertama sebagai berikut:

$\mathbf{Y}_{1}=1,544330+0,118769_{\text {Inflasi }}-0,746920 \mathrm{PE}-0,362937_{\text {Pendidikan }}+\mathrm{e}$

Hasil analisis menunjukkan bahwa nilai $\mathrm{R}^{2}$ sebesar 0,601120 atau $60,11 \%$. Hal ini menunjukkan bahwa sebesar 60,11\% TPT dipengaruhi oleh inflasi, pendidikan dan pertumbuhan ekonomi. Selanjutnya nilai Standar error sebesar 0,073771, apabila semakin kecil nilainya maka akan memnbuat model regresi semakin tepat memprediksi variabel terikat.

Hasil analisis regresi linear berganda mengenai pengaruh inflasi, pendidikan, pertumbuhan ekonomidan tingkat pengangguran terbuka terhadap kemiskinan di Provinsi Jambi dapat dilihat pada Tabel 2.

Tabel 2. Hasil analisis regresi linear berganda persamaan kedua

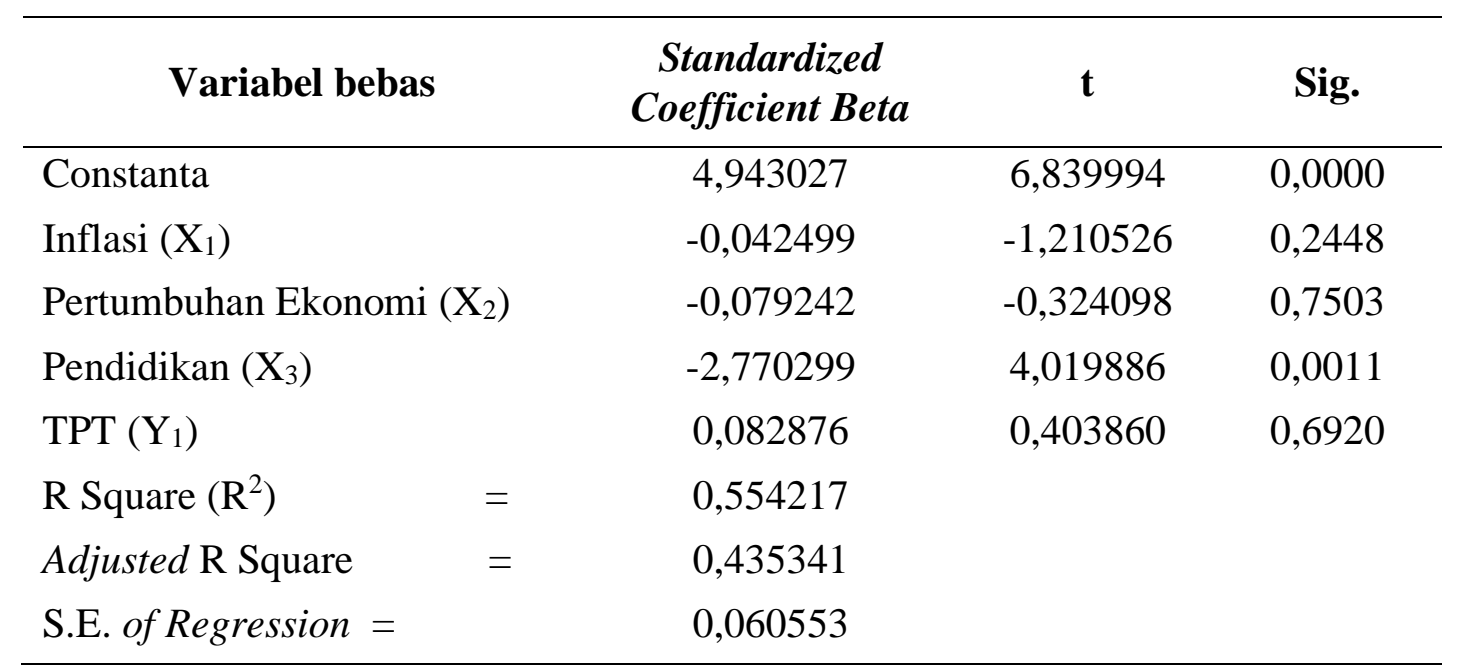

Keterangan $: Y_{2}=$ Kemiskinan

Berdasarkan Tabel 2. maka model persamaan kedua sebagai berikut:

$\mathrm{Y}_{2}=$ 4,943027-0,042499 Inflasi $_{\text {- 0,079242 } \mathrm{PE}}-2,77029$ Pendidikan $_{\text {+ 0,082876 } \mathrm{TPT}}+\mathrm{e}$

Nilai $\mathrm{R}^{2}$ sebesar $0,554217(55,42 \%)$, artinya sebesar $55,42 \%$ kemiskinan di Provinsi jambi dipengaruhi oleh inflasi, pendidikan, pertumbuhan ekonomidan tingkat pengangguran terbuka. nilai Standar error sebesar 0,060553, apabila semakin kecil 
nilainya maka akan memnbuat model regresi semakin tepat memprediksi variabel terikat.

\section{Pengujian hipotesis}

\section{Persamaan pertama}

Untuk menguji persamaan konstanta dari setiap variabel independen dengan menggunakan uji t parsial maka digunakan hipotesis dengan pengambilan keputusan sebagai berikut: a) Jika probabilitas $>0,05$ maka $\mathrm{H}_{0}$ di terima, b) jika probabilitasnya $<0,05$ maka $\mathrm{H}_{0}$ di tolak.

Hasil perhitungan pada Tabel 1. terlihat pengaruh parsial dari maisng-masing Variabel inflasi, pertumbuhan ekonomi dan pendidikan terhadap TPT, maka dapat diambil keputusan sebagai berikut:

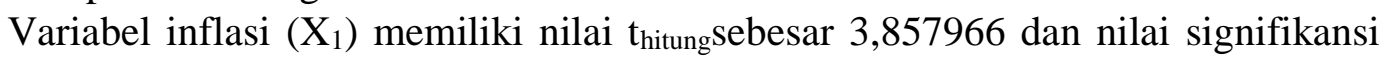
sebesar 0,0014. Hal ini menunjukkan bahwa nilai probabilitas dari variabel inflasi lebih kecil dari $0,05(0,0014<0,05)$, sehingga inflasi berpengaruh signifikan terhadap TPT $\left(\mathrm{Y}_{1}\right)$.

Variabel pertumbuhan ekonomi $\left(\mathrm{X}_{2}\right)$ memiliki nilai thitung sebesar 3,218453 dan nilai signifikansi sebesar 0,0054 . Hal ini menunjukkan bahwa nilai probabilitas dari variabel pertumbuhan ekonomi lebih kecil dari $0,05(0,0054<0,05)$, sehingga pertumbuhan ekonomi berpengaruh signifikan terhadap TPT $\left(\mathrm{Y}_{1}\right)$.

Variabel pendidikan $\left(\mathrm{X}_{3}\right)$ memiliki nilai thitung sebesar $-0,434835$ dan nilai signifikansi sebesar 0,6695 . Hal ini menunjukkan bahwa nilai probabilitas dari variabel pendidikan lebih besar dari $0,05(0,0,6695<0,05)$, sehingga pendidikan berpengaruh signifikan terhadap TPT $\left(\mathrm{Y}_{1}\right)$.

\section{Persamaan Kedua}

Persamaan kedua dilakukan untuk mengetahui pengaruh variabel inflasi, pertumbuhan ekonomi, pendidikan dan TPT terhadap kemiskinan dapat dijelaskan sebagai berikut:

Variabel inflasi $\left(\mathrm{X}_{1}\right)$ memiliki nilai koefisien regresi sebesar $-0,042499$, nilai

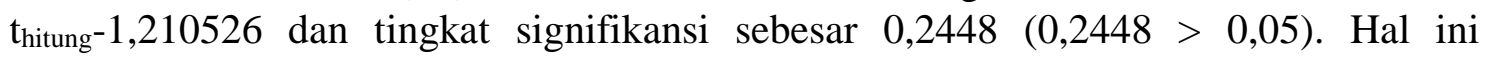
menunjukkan bahwa inflasi berpengaruh tidak signifikan terhadap kemiskinan $\left(\mathrm{Y}_{2}\right)$.

Variabel pertumbuhan ekonomi $\left(\mathrm{X}_{2}\right)$ memiliki nilai koefisien regresi sebesar 0,079242 , nilai $t_{\text {hitung }}-0,324098$ dan tingkat signifikansi sebesar $0,7503(0,7503>0,05)$. Hal ini menunjukkan bahwa pertumbuhan ekonomi berpengaruh tidak signifikan terhadap kemiskinan $\left(\mathrm{Y}_{2}\right)$.

Variabel pendidikan $\left(\mathrm{X}_{3}\right)$ memiliki nilai koefisien regresi sebesar $-2,770299$, nilai $t_{\text {hitung }} 4,019886$ dan tingkat signifikansi sebesar $0,0011(0,0011<0,05)$. Hal ini menunjukkan bahwa pendidikan berpengaruh signifikan terhadap kemiskinan ( $\left.\mathrm{Y}_{2}\right)$.

Variabel TPT $\left(\mathrm{Y}_{1}\right)$ memiliki nilai koefisien regresi sebesar $-0,082876$, nilai $\mathrm{t}_{\text {hitung }} 0,403860$ dan tingkat signifikansi sebesar $0,6920(0,6920>0,05)$. Hal ini menunjukkan bahwa TPT berpengaruh tidak signifikan terhadap kemiskinan $\left(\mathrm{Y}_{2}\right)$.

\section{KESIMPULAN DAN SARAN}

\section{Kesimpulan}

Perkembangan inflasi, pendidikan, pertumbuhan ekonomi, tingkat penganguran terbuka dan kemiskinan di provinsi jambi dari tahun 2000-2019, dimana inflasi tertingi 
terjadi pada tahun 2005 dan terendah pada tahun 2017 dengan rata-rata perkembagan sebesar $11,35 \%$, pendidikan dimana tertingi pada tahun 2019 dan terendah pada tahun 2000 dengan rata-rata perkembangan sebesar $1,25 \%$, pertumbuhan ekonomi dimana tertingi pada tahun 2000 dan terendah pada tahun 2016 dengan perkembangan rata-rata sebesar 5,97\%, TPT dimana tertingi pada tahun 2005 dan terendah pada tahun 2017 dengan rata-rata perkembangan sebesar $5,17 \%$ dan kemiskinan dimana tertingi pada tahun 2000 dan terendah pada tahun 2019 dengan rata-rata perkembangan sebesar $6,51 \%$.

Hasil analisis regresi linear berganda persamaan pertama hanya variabel inflasi dan pertumbuhan ekonomi yang memiliki pengaruh secara signifikan terhadap tingkat penganguran terbuka (TPT) di Provinsi Jambi, sedangkan hasil analisis regresi linear berganda persamaan kedua hanya variabel pendidikan yang memiliki pengaruhi signifikan terhadap variabel kemiskinan kemiskinan di Provinsi Jambi.

\section{Saran}

Diharapkan kepada pemerintah Provinsi Jambi agar dapat memperbaiki perekonomian di Provinsi Jambi supaya menjadi lebih baik sehingga lapangan pekerjaan dan penyerapan tenaga kerja semakin tinggi sehingga tingkat pengangguran terbuka dapat berkurang dan kemiskinan dapat teratasi dengan baik dan jumlah penduduk miskin di Provinsi jambi menajdi lebih rendah dari Provinsi Sumatera Selatan yaitu 1.081,58 jiwa.

Diharapkan kepada seluruh penduduk di Provinsi Jambi terutama yang berada dalam usia sekolah agar meningkatkan kesadaran akan pentingnya pendidikan sehingga kualitas sumberdaya manusia di Provinsi Jambi dapat diperbaiki dan pengangguran serta kemiskinan dapat dikurangi.

\section{DAFTAR PUSTAKA}

Adhi, W.S. (2011). Analisis pengaruh jumlah penduduk, PDRB, IPM, pengangguran terhadap tingkat kemiskinan di Kabupaten/Kota Jawa Tengah. Skripsi Fakultas Ekonomi, Universitas Diponegoro: Semarang.

Amir, A., Junaidi dan Yulmardi. (2019). Metodelogi penelitian ekonomi dan penerapannya. IPB Press: Bogor.

Arsyad, L. (2010). Ekonomi pembangunan. STIM YKPN: Yogyakarta.

Cahyat. (2007). Mengkaji kemiskinan dan kesejahteraan rumah tangga. Dunia Pustaka Jaya: Bandung.

Candra, M. (2011). Pengaruh PDB dan jumlah penduduk terhadap kemiskinan di Indonesia periode 1990-2008.Jurnal Paradigma Ekonomika 1 (4), 12-23

Delis, A., C. Mustika dan E. Umiyati. 2015. Pengaruh FDI terhadap kemiskinan dan pengangguran di Indonesia 1993-2013. Jurnal Paradigma Ekonomika 10 (1), 231-245

Hodijah, S. (2017). Pengaruh pertumbuhan ekonomi, investasi, PAD terhadap kemiskinan melalui kesempatan kerja di Provinsi Jambi. Jurnal Ekonomi dan Kebijakan Publik Indonesia 4 (2), 156-172

P Putriani, J Junaidi, JK Edi. (2019).Pengaruh pertumbuhan ekonomi, pendidikan dan kesehatan terhadap tingkat kemiskinan di Kota Jambi Periode 2004-2017, eJurnal Ekonomi Sumberdaya dan Lingkungan, 7 (3), 132-143 
Romi, S. dan E. Umiyati. (2018). Pengaruh pertumbuhan ekonomi dan upah minimal Terhadap kemiskinan di Kota Jambi. Jurnal Perspektif Ekonomi dan Pembangunan Daerah 7 (1), 1-7

Sugiyono. 2011. Metode penelitian kuantitatif, kualitatif dan $R \& D$. Afabeta: Bandung.

Susanto, E., E. Rochaida dan Y. Ulfah. (2017). Pengaruh inflasi dan Pendidikan terhadap pengangguran dan kemiskinan. Jurnal Inovasi 13 (1), 19-27

Syah, R., S. Hidayat dan E. Achmad. (2013). Faktor-faktor yang mempengaruhi pendapatan rumah tanga miskin di sekitar taman bukit dua belas ( Studi kasus desa-desa penyangga TNBD di Kecamatan Muaro Sebo Ulu Kab Batanghari). Jurnal perspektif Pembiayaan dan Pembangunan daerah 1 (2), 127-136 